\title{
PENERAPAN METODE MULTI ATRIBUT UTILITY THEORY DALAM SISTEM SELEKSI PENERIMAAN DOSEN DI STMIK-AMIK-RIAU.
}

\author{
1) Hadi Asnal, ${ }^{2)}$ Fransiskus Zoromi \\ ${ }^{1,2)}$ Teknik Informatika, STMIK Amik Riau \\ ${ }^{1,2)}$ Jl. Purwodadi Indah Panam Pekanbaru - Riau - Indonesia \\ E-Mail : hadiasnal@stmik-amik-riau.ac.id
}

\begin{abstract}
ABSTRAK
STMIK Amik Amik Riau merupakan sebuah lembaga pendidikan tinggi yang fokus pada ilmu komputer, dalam proses pembelajaran dibutuhkan dosen dengan kualifikasi terbaik, untuk mendapatkan dosen dengan kualifikasi terbaik tersebut diperlukan rangkaian proses seleksi yang objektif, dan sebuah sistem dapat dibangun untuk digunakan didalam proses seleksi ini, sistem yang dibangun menggunakan metode multi atribut utility theory, metode multi atribut utility theory akan digunakan untuk mengolah kriteria yang telah ditentukan sebelumnya, dan kriteria inilah yang akan diolah menjadi sebuah rekomendasi. Metode multi atribut utility theory digunakan untuk membandingkan nilai kuantitatif yang mengkombinasikan pengukuran dari nilai-nilai yang ada. Metode multi atribut utility theory juga digunakan untuk merubah dari beberapa kriteria kedalam nilai numerik. Penulis menargetkan sistem ini mampu memberikan solusi dari masalah yang ada dan memberikan rekomendasi kepada pimpinan dalam menentukan keputusan.
\end{abstract}

Kata Kunci: Dosen, Kriteria, Keputusan

\begin{abstract}
STMIK Amik Amik Riau is an institution of higher education that focuses on computer science, in the learning process required by lecturers with the best qualifications, to get lecturers with the best qualifications needed for an objective selection process, and a system that can be built to be used to involve this selection process, a system built using the multi-attribute utility theory method, the multi-attribute utility theory method will be used to process predetermined criteria, and this criterion will be processed into a recommendation. Multi attribute attribute theory is used to compare quantitative values that combine measurements from existing values. Multi-attribute utility theory is also used to convert several criteria into numerical values. The author agrees that this system provides solutions to existing problems and provides recommendations to leaders in determining decisions
\end{abstract}

Keyword: Lecturers, Criteria, Decisions.

\section{PENDAHULUAN}

STMIK Amik Riau merupakan perguruan tinggi yang secara khusus dan fokus pada ilmu komputer. Dalam pelaksanaan proses pembelajaran di STMIK Amik Riau tentu dibutuhkan dosen dengan kriteria dan kemapuan khusus, semakin baik kualitas dosen tentu akan semakin baik pula dampaknya terhadap banyak hal bagi institusi STMIK Amik Riau. Untuk mendapatkan dosen yang terbaik tentu dimulai dari awal proses yaitu proses seleksi perekrutan dosen.

Selama ini proses seleksi saat perekrutan telah dilakukan, namun proses yang ada selama ini hanya berupa tes tertulis, wawancara serta tes kemampuan mengajar, jika pun melihat kriteria lain seperti penampilan, pengalaman mengajar dan lainnya hanya sebatas pertimbangan saja, padahal banyak kriteria lain yang sangat menentukan, dalam proses seleksi penerimaan dosen juga belum dikelola dengan sistem tertentu yang mampu memberikan rekomendasi bagi pimpinan dalam menentukan keputusan dan selama ini masih bergantung pada proses manual saja.

Atas dasar inilah penulis menganggap perlu dibangun sebuah sistem yamg mampu memberikan solusi bagi masalah tersebut, sistem yang akan dibangun adalah sistem seleksi penerimaan dosen yang nantinya mampu memberikan rekomendasi siapa saja yang layak untuk menjadi dosen di STMIK 
Amik Riau, sistem ini akan dibangun dengan menggunakan metode multi atribut utility theory, metode multi atribut utility theory akan digunakan untuk mengolah kriteria yang telah ditentukan sebelumnya, dan kriteria inilah yang akan diolah menjadi sebuah rekomendasi. Metode multi atribut utility theory digunakan untuk membandingkan nilai kuantitatif yang mengkombinasikan pengukuran dari nilai-nilai yang ada. Metode multi atribut utility theory juga digunakan untuk merubah dari beberapa kriteria kedalam nilai numerik mewakili nilai terburuk dan nilai terbaik.

Dengan adanya sistem ini ditargetkan mampu menjadi solusi dari masalah yang ada dan membantu pimpinan dalam menentukan keputusan dosen yang terbaik.

\section{Sistem}

Sistem merupakan serangkaian data atau lebih komponen yangsaling terkait dan berinteraksi untuk mencapai tujuan [1]. Sedangkan menurut Jogiyanto Sistem adalah kumpulan dari elemen - elemen yang berinteraksi untuk mencapai suatu tujuan tertentu [2].

\section{Sistem Pendukung Keputusan}

Sistem pendukung keputusan merupakan sistem informasi interaktif yang menyediakan informasi, pemodelan, dan pemanipulasian data yang digunakan untuk membantu pengambilan keputusan pada situasi yang semi- terstruktur dan tidak terstruktur di mana tak seorang pun tahu secara pasti bagaimana keputusan seharusnya dibuat [3].

Sedangkan menurut Tri et al., 2013

Sistem Pendukung Keputusan merupakan pasangan, intelektual dari sumber daya manusia dengan kemampuan komputer untuk memperbaiki keputusan, yaitu sistem pendukung keputusan berbasis komputer bagi pembuat keputusan manajemen yang menghadapi masalah tidak terstruktur [4].

\section{Karakteristik Pendukung Keputusan}

Menurut Turban karakteristik sistem keputusan adalah sebagai berikut:

a. Dukungan kepada pengambil keputusan, terutama pada situasi semi terstruktur dan tak terstruktur, dengan menyertakan penilaian manusia dan informasi terkomputerisasi. Masalahmasalah tersebut tidak bisa di pecahkan oleh sistem komputer lain atau oleh metode atau alat kuantitatif standar.

b. Dukungan untuk semua level manajerial, dari eksekutif puncak sampai manajer lini.

c. Dukungan untuk semua individu dan kelompok. Masalah yang kurang terstruktur sering memerlukan keterlibatan individu dari departemen dan tingkat organisasional yang berbeda atau bahkan dari organisasi lain.

d. Dukungan untuk keputusan independen dan atau sekuensial. Keputusan bisa di buat satu kali, beberapa kali, atau berulang (dalam interval yang sama).

e. Dukungan di semua fase proses pengambilan keputusan: intelegensi, desain, pilihan, dan implementasi.

f. Dukungan di berbagai proses dan gaya pengambilan keputusan.

g. Adaptivitas sepanjang waktu. Pengambil keputusan seharusnya reaktif, bisa menghadapi perubahan kondisi secara cepat, dan mengadaptasi Sistem Pendukung Keputusan untuk memenuhi perubahan tersebut. Sistem Pendukung Keputusan bersifat fleksibel. Oleh karena itu, pengguna bisa menambahkan, menghapus, menggabungkan, mengubah, atau menyusun kembali elemen-elemen 
dasar. Sistem Pendukung Keputusan juga fleksibel dalam hal ini bisa di modifikasi untuk memecahkan masalah lain yang sejenis.

h. Ramah pengguna, kapabilitas grafis yang sangat kuat, dan antarmuka manusia-mesin yang interaktif dengan satu bahasa alami bisa sangat meningkatkan efektivitas Sistem Pendukung Keputusan.

i. Peningkatan efektivitas pengambilan keputusan (akurasi, timeliness, kualitas) ketimbang pada efisiennya (biaya pengambilan keputusan). Ketika Sistem Pendukung Keputusan disebarkan, pengambilan keputusan sering membutuhkan waktu yang lebih lama, tetapi hasilnya lebih baik.

j. Kontrol penuh oleh pengambil keputusan terhadap semua langkah proses pengambilan keputusan dalam memecahkan suatu masalah. Sistem Pendukung Keputusan secara khusus menekankan untuk mendukung pengambilan keputusan, bukannya menggantikan.

k. Pengguna akhir bisa mengembangkan dan memodifikasi sendiri sistem sederhana. Sistem yang lebih besar bisa di bangun dengan bantuan ahli sistem informasi. Perangkat lunak OLAP dalam kaitannya dengan data warehouse memperbolehkan pengguna untuk membangun Sistem Pendukung Keputusan yang cukup besar dan komplek.

1. Biasanya, model-model di gunakan untuk menganalisis situasi pengambilan keputusan. Kapabilitas pemodelan memungkinkan eksperimen dengan berbagai strategi yang berbeda di bawah konfigurasi yang berbeda.

m. Akses di sediakan untuk berbagi sumber data, format, dan tipe, mulai dari sistem informasi geografis (GIS) sampai sistem berorientasi objek.

n. Dapat di gunakan sebagai alat standalone oleh seorang pengambil keputusan pada satu lokasi atau di distribusikan di suatu organisasi secara keseluruhan dan di beberapa organisasi sepanjang rantai persediaan. Dapat di integrasikan dengan Sistem Pendukung Keputusan lain dan atau aplikasi lain, serta bisa di distribusikan secara internal dan eksternal menggunakan networking dan teknologi Web [5].

\section{Metode Multi Atribut Utility Theory.}

Metode Multi Attribute Utility Theory merupakan suatu metode perbandingan kuantitatif yang biasanya mengkombinasikan pengukuran atas biaya resiko dan keuntungan yang berbeda. Setiap kriteria yang ada memiliki beberapa alternatif yang mampu memberikan solusi. Untuk mencari alternatif yang mendekati dengan keinginan user maka untuk mengidentifikasikannya dilakukan perkalian terhadap skala prioritas yang sudah ditentukan. Sehingga hasil yang terbaik dan paling mendekati dari alternatifalternatif tersebut yang akan diambil sebagai solusi [6].

Metode multi atribut utility theory digunakan untuk merubah dari beberapa kepentingan kedalam nilai numerik dengan skala 0-1 dengan 0 mewakili pilihan terburuk dan 1 terbaik. Hal ini memungkinkan perbandingan langsung yang beragam ukuran [7].

Sedangkan tahapan yang digunakan adalah sebagai berikut :

a. Pecahkan keputusan kedalam dimensi yang berbeda. 
b. Tentukan bobot relatif pada masingmasing dimensi.

c. Daftar semua alternatif.

d. Menghitung nilai Utility normalisasi matriks untuk masing-masing alternatif sesuai atributnya, dengan rumus :

$$
u(x)=\frac{\left(x-x i^{-}\right)}{x i^{+}-x i^{-}}
$$

$$
\begin{aligned}
& u(x)=\text { Normalisasi bobot alternatif } \\
& x=\text { Bobot Alternatif } \\
& x i^{+}=\text {Nilai kriteria maksimal } \\
& x i^{-}=\text {Nilai kriteria minimal }
\end{aligned}
$$

e. Kalikan utility dengan bobot untuk menemukan nilai masing-masing alternatif [8].

\section{METODE}

\section{Kerangka Kerja Penelitian}

Kerangka kerja penelitian digunakan untuk mengetahui tahapan-tahapan yang ada dalam penelitian ini, adapun tahapan yang dimaksud adalah sebagai berikut :

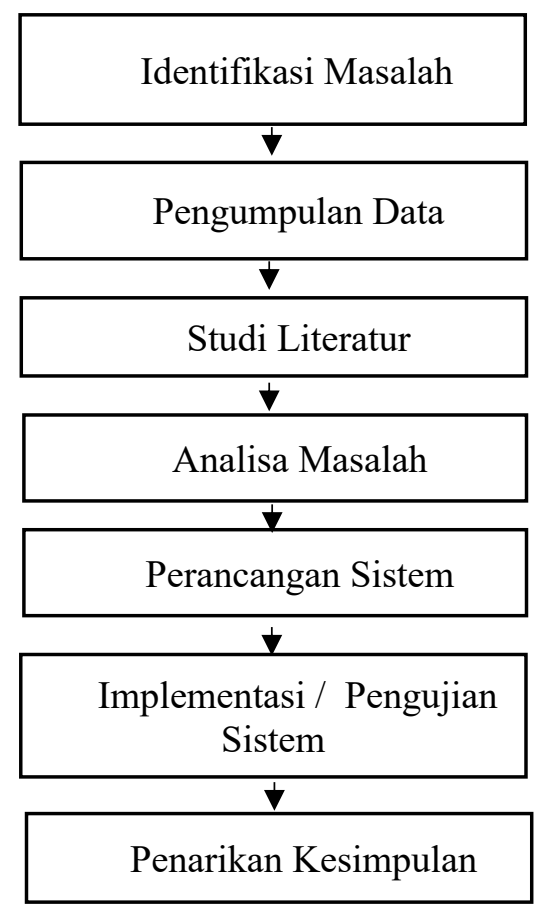

Gambar 1. Kerangka Kerja Penelitian a. Identifikasi Masalah.

Identifikasi masalah merupakan tahapan awal untuk memetakan permasalahan yang ada, sehingga ditemukan permasalahan yang sebenarnya.

b. Pengumpulan Data.

Pengumpulan data dalam penelitian ini dilakukan dengan beberapa metode pengumpulan data yaitu:

i. Observasi.

Observasi digunakan untuk lebih memahami bagaimana prosedur penerimaan dosen selama ini, hal ini dilakukan langsung di unit kerja program studi, khususnya program studi Teknik Informatika sebagai program studi tertua yang memahamibagaimana memetakan dosen yang dibutuhkan selama ini.

ii. Wawancara.

Wawancara yang dilakukan dengan tanya jawab kepada Wakil ketua 2 yang menaungi penerimaan dosen, serta kaprodi khususnya kaprodi Teknik Informatika yang memahami masalah kebutuhan dosen.

c. Studi Literatur.

Studi literatur digunakan untuk mempelajari ataupun menambah pemahaman peneliti tentang sistem pendukung keputusan secara umum dan meode Multi atribut utility theory secara khusus serta literatur terkait lainnya yang diperolah dari jurnal, buku maupun tugas akhir mahasiswa. 
d. Analisa Masalah.

Analisa masalah digunakan untuk memecahkan masalah, menganalisis pola-pola yang ada di dalam data melakukan kajian sebelum dilakukan perancangan.

e. Perancangan Sistem.

Tahapan ini dilakukan dengan menggunakan bahasa pemrograman, bahasa pemrograman yang digunakan dalam penelitian ini adalah bahasa pemrograman Hypertext Processor (PHP).

f. Implementasi dan Pengujian.

Sistem yang telah berhasil dirancang harus dilakukan implementasi dan pengujian untuk melihat apakah telah sesuai dengan kebutuhan, dan implementasi dilakukan dengan menggunakan data sample calon dosen.

g. Penarikan Kesimpulan

Tahapan akhir adalah membuat kesimpulan dari seluruh proses penelitian ini, untuk melihat apakah sebuah hipotesis awal diatas sesuai atau tidak, kesimpulan juga menjadi intisari dari hasil penelitian ini.

\section{Penerapan Metode Multi Atribut Utility Theory. \\ A. Memecahkan keputusan kedalam dimensi yang berbeda.}

Keputusan dikelompokkan kedalam matrik keputusan berikut :
h. Sangat Layak $=0.8 \mathrm{~s} / \mathrm{d} 1$
i. Layak
$=0.6 \mathrm{~s} / \mathrm{d} 0.7$
j. Cukup
$=0.4 \mathrm{~s} / \mathrm{d} 0.5$
k. Tidak Layak
$=0 \mathrm{~s} / \mathrm{d} 0.3$

\section{B. Menentukan bobot relative pada masing-masing dimensi.}

Kriteria yang telah ditentukan harus ditetapkan persentasenya, persentase didapat dari pertimbangan berdasarkan tingkat kepentingan atau derajat setiap kriteria, berikut persentase masing-masing kriteria :

Tabel 1. Tabel Bobot Relative

\begin{tabular}{ccc}
\hline $\begin{array}{c}\text { Kode } \\
\text { Kriteria }\end{array}$ & Kriteria & $\begin{array}{c}\text { Bobot } \\
\text { Relative }\end{array}$ \\
\hline KK01 & Kemampuan Mengajar & $20 \%$ \\
\hline KK02 & Kesehatan & $5 \%$ \\
\hline KK03 & Tes Tertulis & $10 \%$ \\
\hline KK04 & $\begin{array}{c}\text { Pengalaman Kerja } \\
\text { Sebagai Dosen }\end{array}$ & $20 \%$ \\
\hline KK05 & Wawancara & $10 \%$ \\
\hline KK06 & Sertifikat \\
& PEKERTI/AA & $20 \%$ \\
\hline KK07 & Penampilan & $5 \%$ \\
\hline KK08 & IPK Pendidikan & $10 \%$ \\
& Terakhir $>3.5$ & $100 \%$ \\
\hline Total & &
\end{tabular}

Tabel 2: Tabel Bobot Point

\begin{tabular}{ccc}
\hline $\begin{array}{c}\text { Kode } \\
\text { Kriteria } \\
(\text { KK) }\end{array}$ & Kriteria & $\begin{array}{c}\text { Bobot } \\
\text { Point }\end{array}$ \\
\hline KK01 & $\begin{array}{c}\text { Kemampuan } \\
\text { Mengajar }\end{array}$ & $1 / 2 / 3 / 4$ \\
& Kesehatan & $1 / 3$ \\
\hline KK02 & Tes Tertulis & $1 / 2 / 3 / 4$ \\
\hline KK03 & Pengalaman Kerja \\
\hline KK04 & $1 / 3$ \\
& Sebagai Dosen \\
\hline KK05 & Wawancara & $1 / 2 / 3 / 4$ \\
\hline KK06 & Sertifikat \\
\multicolumn{3}{c}{ PEKERTI/AA } \\
\hline KK07 & Penampilan & $1 / 3$ \\
\hline & IPK Pendidikan \\
Terakhir $>3.5$ & $1 / 3 / 4$ \\
\hline
\end{tabular}

\section{Daftar Semua Alternatif.}

Tahap ini digunakan untuk menetapkan alternatif kedalam sistem, dan 
alternatif dalam penelitian ini adalah calon dosen yang melamar sebagai dosen, terdapat data 10 calon dosen yang akan diuji sebagai contoh untuk mengetahui keputusan atau hasil dari setiap dosen. dan seterus nya dalam contoh kasus nantinya sebutan calon dosen akan disingkat ( CD ).

\section{Nilai Utility.}

Calon dosen yang telah melewati rangkaian tes dan verifikasi berkas diberikan bobot point berdasarkan kondisi real dari setiap calon dosen, bobot point inilah yang akan diolah mengikuti aturan yang ada didalam Metode Multi Attribute Utility Theory .

Berikut adalah tabel bobot calon dosen yang diperoleh dari rangkaian hasil tes dan verifikasi berkas.

Tabel 3. Tabel Bobot Calon Dosen

\begin{tabular}{ccccccccc}
\hline Calon & $\mathbf{K}$ & $\mathbf{K}$ & $\mathbf{K}$ & $\mathbf{K}$ & $\mathbf{K}$ & $\mathbf{K}$ & $\mathbf{K}$ & $\mathbf{K}$ \\
Dosen & $\mathbf{K}$ & $\mathbf{K}$ & $\mathbf{K}$ & $\mathbf{K}$ & $\mathbf{K}$ & $\mathbf{K}$ & $\mathbf{K}$ & $\mathbf{K}$ \\
(CD) & $\mathbf{0}$ & $\mathbf{0}$ & $\mathbf{0}$ & $\mathbf{0}$ & $\mathbf{0}$ & $\mathbf{0}$ & $\mathbf{0}$ & $\mathbf{0}$ \\
& $\mathbf{1}$ & $\mathbf{2}$ & $\mathbf{3}$ & $\mathbf{4}$ & $\mathbf{5}$ & $\mathbf{6}$ & $\mathbf{7}$ & $\mathbf{8}$ \\
\hline CD001 & 2 & 1 & 3 & 3 & 2 & 1 & 2 & 3 \\
\hline CD002 & 3 & 3 & 2 & 1 & 3 & 1 & 3 & 3 \\
\hline CD003 & 2 & 3 & 2 & 1 & 1 & 1 & 2 & 1 \\
\hline CD004 & 4 & 3 & 2 & 1 & 1 & 1 & 3 & 3 \\
\hline CD005 & 4 & 3 & 3 & 1 & 4 & 3 & 4 & 3 \\
\hline CD006 & 3 & 3 & 2 & 1 & 2 & 1 & 4 & 1 \\
\hline CD007 & 2 & 1 & 3 & 1 & 4 & 1 & 3 & 1 \\
\hline CD008 & 3 & 3 & 3 & 3 & 4 & 1 & 1 & 3 \\
\hline CD009 & 3 & 3 & 2 & 1 & 3 & 1 & 3 & 1 \\
\hline CD010 & 1 & 3 & 4 & 1 & 3 & 1 & 3 & 1 \\
\hline
\end{tabular}

\section{E. Perkalian Utility dengan Bobot.}

Rumus yang digunakan adalah:

$$
u(x)=\frac{\left(x-x i^{-}\right)}{x i^{+}-x i^{-}}
$$

$$
\begin{aligned}
& u(x)=\text { Normalisasi bobot alternatif } \\
& x \quad=\text { Bobot Alternatif } \\
& x i^{+}=\text {Nilai kriteria maksimal } \\
& x i^{-}=\text {Nilai kriteria minimal }
\end{aligned}
$$

Untuk realisasi dapat dijelaskan dengan contoh kasus berikut ini, serta pembuktian kesamaan hasil contoh kasus dengan program yang dibuat dapat dilihat pada bab IV.

Contoh Kasus pada Calon Dosen 1 (CD001).

$$
\begin{aligned}
\mathrm{KK} 01 & =\frac{2-\mathbf{1}}{\mathbf{4 - 1}}=\frac{\mathbf{1}}{\mathbf{3}}=0.33 \\
& =20 \% \times 0.33=0.06
\end{aligned}
$$

$$
\begin{aligned}
\mathrm{KK} 02 & =\frac{\mathbf{1 - 1}}{\mathbf{3 - 1}}=\frac{\mathbf{0}}{2}=0 \\
& =5 \% \times 0=0 \\
\mathrm{KK} 03 & =\frac{3-\mathbf{1}}{\mathbf{4 - 1}}=\frac{2}{3}=0.6 \\
& =10 \% \times 0.6=0.06
\end{aligned}
$$

$\mathrm{KK} 04=\frac{3-1}{3-1}=\frac{2}{2}=1$

$$
=20 \% \times 1=0.2
$$

$\mathrm{KK} 05=\frac{2-1}{4-1}=\frac{1}{3}=0.33$

$$
=10 \% \times 0.33=0.03
$$

$\mathrm{KK} 06=\frac{\mathbf{1 - 1}}{3-1}=\frac{\mathbf{0}}{\mathbf{2}}=0$ 


$$
20 \% \times 0=0
$$

$$
\begin{aligned}
\mathrm{KK} 07 & =\frac{2-1}{4-1}=\frac{1}{3}=0.33 \\
& =5 \% \times 0.33=0.01
\end{aligned}
$$

$$
\begin{aligned}
\mathrm{KK} 08 & =\frac{\mathbf{3 - 1}}{\mathbf{3 - 1}}=\frac{\mathbf{2}}{\mathbf{2}}=1 \\
& =10 \% \times 1=0.1
\end{aligned}
$$

Selanjutnya dilakukan penjumlahan dari nilai akhir penghitungan yaitu :

$$
\begin{aligned}
& \text { KK01+ KK02+ KK03+ KK04+ KK05+ } \\
& \text { KK06 }+ \text { KK07+ KK08 atau } \\
& 0.06+0+0.06+0.2+0.03+0+0.01+0.1=0.46
\end{aligned}
$$

Maka nilai 0.46 adalah ( Cukup ).

\section{HASIL}

\section{Perancangan Proses}

\section{Pemodelan UML}

Use Case Diagram

Usecase diagram digunakan untuk menggambarkan hubungan yang ada antara sistem yang dibangun dengan pengguna.

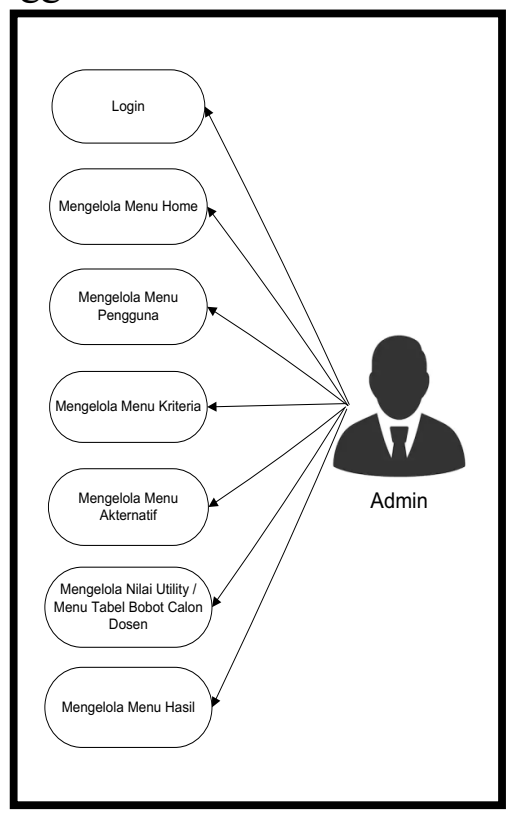

Gambar 2. Usecase Diagram

\section{Implementasi}

Tahapan

implementasi sistem merupakan tahap untuk membuktikan apakah sistem telah berjalan sesuai dengan kalkukasi di metode. Adapun spesifikasi dari perangkat keras dan perangkat lunak yang digunakan dalam tahap implementasi sistem ini yaitu :

a. Perangkat Keras.

i. PC Intel (R) Pentium (R) CPU G2010@2.80GHz

ii. RAM 2.00 GB (1.89 GB Usable)

iii. System Type 32 bit OS

b. Perangkat Lunak.

i. $\quad$ Microsoft Office 2013

ii. PHP

iii. Snipping Tool

iv. Balsamiq

v. Microsoft Visio

\section{Tampilan Login}

Tampilan Login adalah tampilan awal masuk kedalam link yang telah dibuat, seorang admin perlu memasukkan username dan password dengan benar agar bisa masuk untuk mengelola sistem.

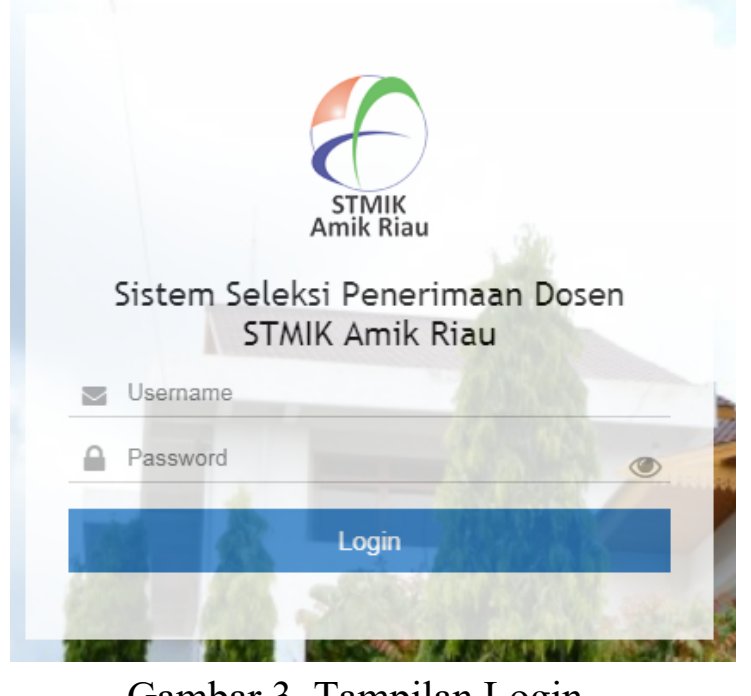

Gambar 3. Tampilan Login 


\section{Tampilan Home}

Tampilan Home adalah tampilan utama sebelum masuk kesemua menu yang telah disediakan.



Sistem Seleksi Penerimaan Dosen STMIK Amik Riau

Gambar 4. Tampilan Home

\section{Tampilan Halaman Pengguna.}

Tampilan Halaman Pengguna digunakan untuk mengetahui siapa saja yang memiliki hak akses untuk masuk kedalam sistem ini, dan dapat pula dilakukan penambahan pengguna apabila diperlukan, sejauh ini admin lah yang memiliki domain untuk bisa masuk kedalam sistem, namun jika diperlukan dapat juga diberikan akses kepada user lain seperti wakil ketua 2 bidang keuangan / personalia atau Ketua program studi yang ada di STMIK Amik Riau.

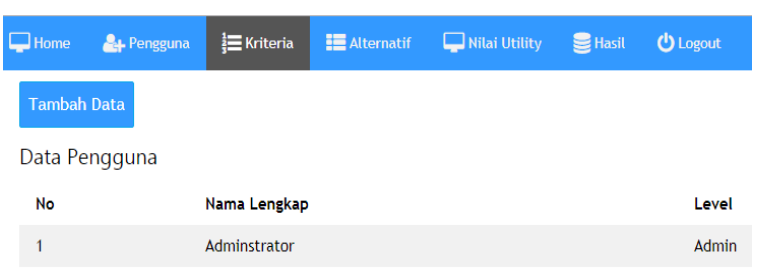

Gambar 5. Tampilan Halaman Pengguna

\section{Tampilan Data Kriteria.}

Tampilan Data Kriteria merupakan menu yang dibuat untuk melihat kriteria, termasuk persen dan range nilai yang ada, dan apabila ada perubahan, penambahan atau penghapusan data kriteria hingga perubahan bobot point dapat dilakukan dimenu ini.

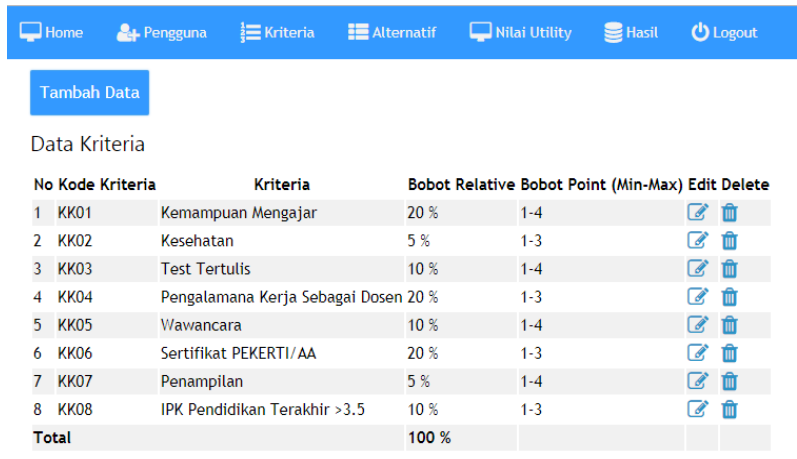

Gambar 6. Tampilan Data Kriteria

\section{Tampilan Data Alternatif.}

Tampilan Data Alternatif digunakan untuk melihat data seluruh calon dosen termasuk penambahan, perubahan, penghapusan data dosen dapat dilakukan pada menu ini.

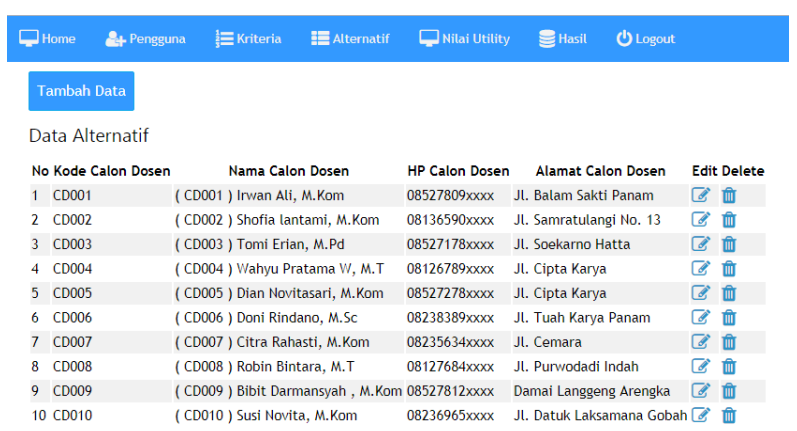

Gambar 7. Tampilan Data Alternatif

\section{Tampilan Tabel Bobot Calon Dosen}

Tampilan Tabel Bobot Calon Dosen digunakan untuk melihat bobot nilai pada tiap kriteria dari seluruh calon dosen.

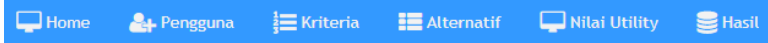

\begin{tabular}{|c|c|c|c|c|c|c|c|c|c|}
\hline No & Calon Dosen (CD) & кко & KKo & KK03 & KKO4 & KKO5 & KKOG & KK07 & KK08 \\
\hline & ( CD001) Irwan Ali, M.Kom & 2 & 1 & 3 & 3 & 2 & 1 & 2 & 3 \\
\hline 2 & ( CD002 ) Shofia lantami, M.Kom & 3 & 3 & 2 & 1 & 3 & 1 & 3 & 3 \\
\hline 3 & ( $\mathrm{CD} 003$ ) Tomi Erian, M.Pd & 2 & 3 & 2 & 1 & 1 & 1 & 2 & 1 \\
\hline 4 & ( CD004) Wahyu Pratama W, M.T & 4 & 3 & 2 & 1 & 1 & 1 & 3 & 3 \\
\hline 5 & ( CD005) Dian Novitasari, M.Kom & 4 & 3 & 3 & 1 & 4 & 3 & 4 & 3 \\
\hline 6 & ( CD006) Doni Rindano, M.Sc & 3 & 3 & 2 & 1 & 2 & 1 & 4 & 1 \\
\hline 7 & ( CD007) Citra Rahasti, M.Kom & 2 & 1 & 3 & 1 & 4 & 1 & 3 & 1 \\
\hline 8 & ( CD008) Robin Bintara, M.T & 3 & 3 & 3 & 3 & 4 & 1 & 1 & 3 \\
\hline & (CD009) Bibit Darmansyah , M.Kom & 3 & 3 & 2 & 1 & 3 & 1 & 3 & 1 \\
\hline & ( CD010) Susi Novita, M.Kom & 2 & 1 & 3 & 3 & 2 & 1 & 2 & 3 \\
\hline
\end{tabular}

Gambar 8. Tampilan Bobot Calon Dosen 


\section{Tampilan Hasil.}

Tampilan Hasil perhitungan dengan metode Multi Atribut Ultility Theory adalah bagian akhir dari sistem, digunakan untuk memuat keseluruahan proses, hasil setiap bobot point hingga nilai akhir yang disebut total nilai dan terlihat hasil berupa tidak layak, cukup, layak dan sangat layak.

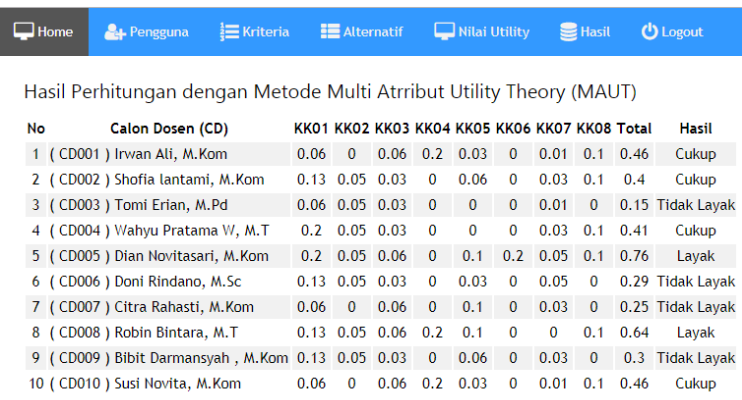

Gambar 9. Tampilan Hasil

\section{KESIMPULAN}

Berdasarkan hasil penelitian maka dapat disimpulkan beberapa hal, yaitu:

a) Sistem yang dibangun menunjukkan mampu menjadi solusi dari permasalahan seleksi dalam perekrutan dosen baru.

b) Metode Multi Atribut Utility Theory dapat diterapkan dalam membangun sistem seleksi penerimaan dosen STMIK Amik Riau.

c) Hasil diperoleh dengan perhitungan yang jelas dan objektif.

d) Dari pengujian berdasarkan data yang ada diperoleh dua orang calon dosen yang layak dengan nilai CD008 $=0,64$ dan $\mathrm{CD} 005=0,76$.

e) Hasil yang diperoleh hanya bersifat rekomendasi bagi pimpinan dalam menentukan keputusan yang terkait dengan penerimaan dosen.

\section{DAFTAR PUSTAKA}

[1] Romney, Marshal B, Paul John Steinbert., 2015. Accounting Information Systems, Salemba Empat,Jakarta.

[2] Jogiyanto, HM. 2008. Analisis dan Desain Sistem Informasi: Pendekatan Terstruktr teori dan praktek Aplikasi Bisnis. Yogyakarta: Andi Offset.

[3] Agus Perdana Windarto, "Implementasi metode topsis dan saw dalam memberikan reward pelanggan”, Kumpul. J. Ilmu Komput., vol. 4, no. 1, pp. 88-101, 2017.

[4] Tri, Afriliyanti., dan Sri Winarti., "Perancangan Sistem Pendukung Keputusan Penentuan Rumah Sehat", Jurnal Sarjana Teknik Informatika Volume 1 Nomor 2, Oktober 2013, e-ISSN: 2338-5197.

[5] Turban, Efraim, DKk. 2005. Decission Support System and Intelligent Systems. Yogyakarta: Graha Ilmu.

[6] Anugerah, Sandy. 2008. Rancang Bangun AplikasiPanduan Modifikasi Kendaraan Roda Empat Pada Mobile Device Dengan Metode MultiAttribute Utility Theory (Maut). Surabaya:Institut Teknologi Sepuluh Nopember. Surabaya.

[7] MGusdha, Eka Andrita, dkk,"'Sistem Promosi Jabatan Karyawan dengan Metode AnalyticalHierarchy Process (AHP) dan Multi-Attribute Utility Theory (MAUT), (Studi Kasus pada PT. Ginsa Inti Pratama)", Universitas Indonesia. 
[8] Novri Hadinata, "Implementasi Metode Multi Attribute Utility Theory (MAUT) Pada Sistem Pendukung Keputusan dalam Menentukan Penerima Kredit ", Jurnal Sisfokom. Vol:07,02 Sept 2018. 